\title{
サステナブルビル構造システムの提案とその基本特性 \\ ONE PROPOSAL FOR A SUSTAINABLE BUILDING STRUCTURE SYSTEM AND ITS BASIC PROPERTIES
}

\author{
會澤貴浩*, 山田 哲**, 岩田 衛*** \\ Takahiro AIZAWA, Satoshi YAMADA and Mamoru IWATA
}

\begin{abstract}
Long service life, reuse and recycling and three primary measures for reducing environmental burden in building field. A sutainable building structure system enables the environmental burden to reduce. This structural system, which is a kind of damage-controlled structure, consists of columns, beams like knee brace. Since the connections are semi-rigid, there is no large bending moment occurring in earthquake, and the columns and beams suffer no damage. The buckling-restrained knee braces only absorb seismic energy. The columns and beams are connected with special long bolts alone, facilitating demolition of the structure and able to be reused the members. In this sudy, full-scale experiments of the connection were carried out. Based on these results, structural models, which modeled the connection, were analyzed, and the structural system was verified.
\end{abstract}

Keywords : Environmental burden, Reuse, Damage-controlled structure, Full-scale experiment, Seismic response analysis

環境負荷、リニース、損賃制御構造、実大実験、地震応答解析

\section{1。序籍}

著者らは、鉄骨造中圓集合住宅のライフサイクルにおける環境負 荷削減のシナリオとその評価を、廃亩物量と $\mathrm{LCCO}_{2}$ に着目して定量 的に分析した ${ }^{1) 2 。}$ 。この研究結果から、建策桠造の耐用年数を 100 〜 150 年程度に上げると大偪な㻴境負荷削隇ができること、それが 叶わない場合には、 $\mathrm{CO}_{2}$ 排出量の観点からして、鉄骨部材をリサイク ルではなく、リユースするべきであることを明らかにしてきた。リ ユースは、最近ニーズが出てきている期限付き建築物や短寿命建築 物にとっても有勃であるが、現在までに市場が成立していない。そ こで、情報技術を利用した建築銅構造のリユースマネジメントモデ ルを提案し3)、経済的に成立する可能性も示した。

以上の研究成果を踏まえ、構造全体の長寿命化を第一に、それが 叶わない時には、部材のリユースを可能とする「サステナブルビル 構造システム」の実現を図ることを考えた4)。この構造システムは、 損甥した各部材、部品を取替えることにより、構造全体の持綍性を 図り、必要に祭しては解体が容易でリユースができる部材によって 構成される、損傷制御構造 ${ }^{5}$ の一つの形式とする。すなわち、重力 を支持する柱梁からなる主架樓を、たとえ大地震を受けても弾性域 に留め、地震力を負担する制振部材のみに損倁を集約する。着想し た構造システムの柱梁接合部には、大きな曲げモーメントが生じな
い新接合方法を採用し、柱と梁に制振部材としての座屈拘束ブレー スを方杖のように設㯰し、座屈拘束ニーブレース（以下、ブレース） とする。

本論文では、先ず着想した構造システムとその接合方法の概要を 述べる。この種の柱梁接合方法に関しては、最近、幾つかの研究 ${ }^{6)}$ 7)8）が報告されている。しかし、次節で述べるように、着想した接 合方法は全く新しい特徵と忍力伝達機践を有するものである。次に、

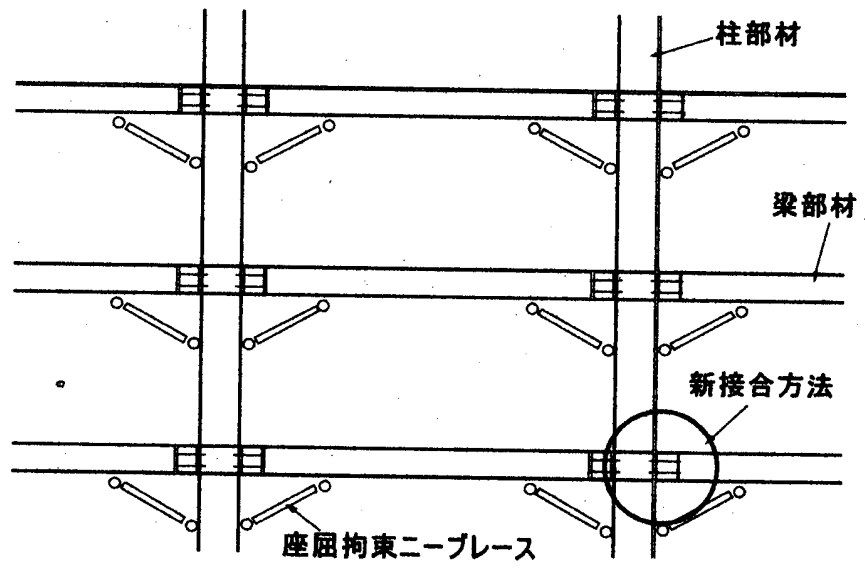

図.1 サステナブルビル構造システム

\footnotetext{
藤沢市役所 修士(工学)

(当時 神奈川大学 大学院生)

** 東京工業大学建築物理研究センター 助教授・博士 (工学)

*** 神奈川大学工学部建築学科 教授・工博
}

Fujisawa City Office, M. Eng.

(Former Graduate Student, Kanagawa Univ.)

Assoc. Prof., Structural Engineering Research Center, Tokyo Institute of Technology, Dr. Eng.

Prof., Dept. of Architecture and Building Engineering, Faculty of Engineering Kanagawa Univ., Dr. Eng. 


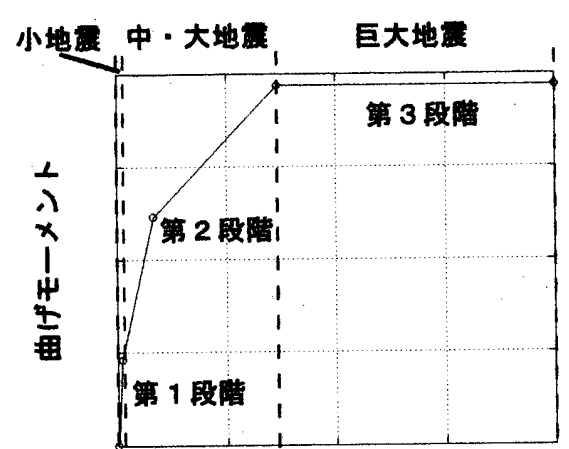

回転角

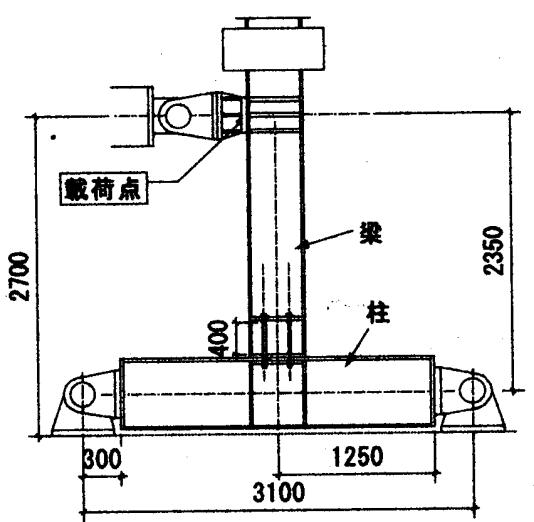

图 4 实験裝贯

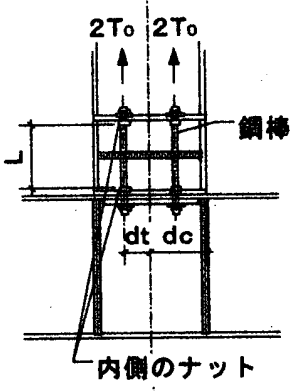

图 5 接合部鲜細
图2 曲げモーメントー回転角関保

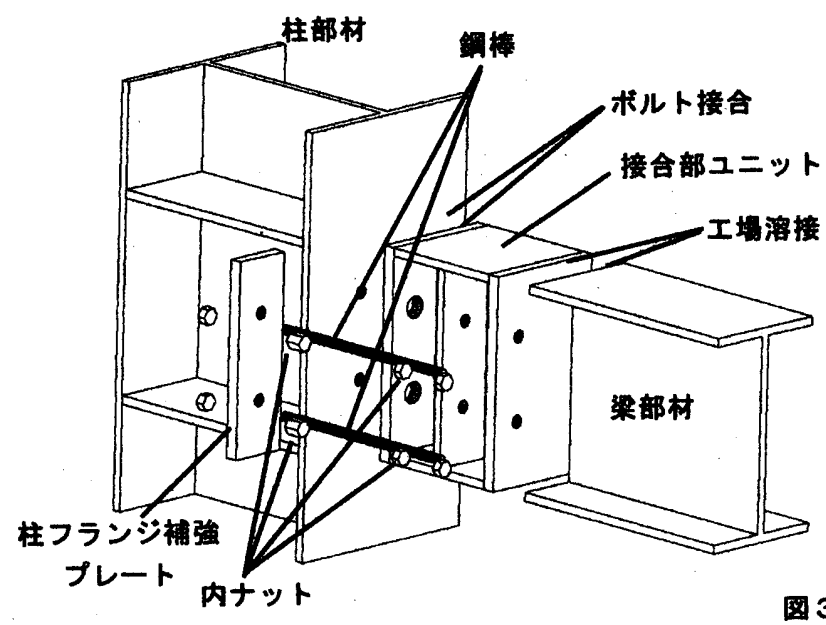

国 3

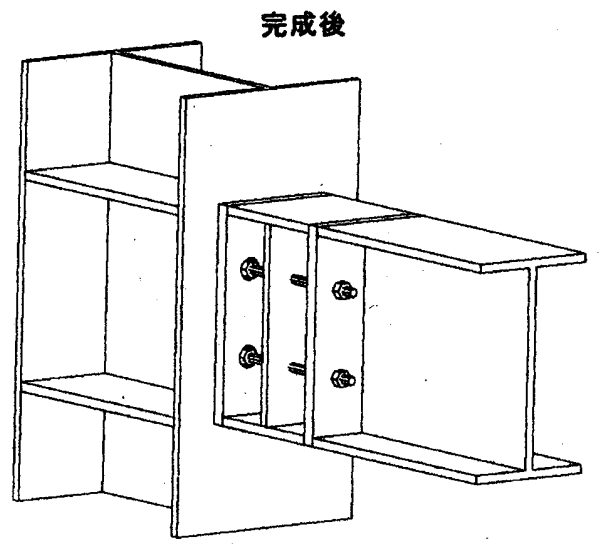

この新柱梁接合方法の性能確認実験を行い、構造特性を把握する。 それらの実験結果を踏まえ、接合部の力学モデルを検討する。更に、 既往の研究で性能が明らかにされている座屈拘束ブレース ${ }^{91}$ と、新 接合方法が組み合わされた時の基本的挙動を確認するために、部分 架構実跧を行う。最後に、接合部力学モデルを用いた全体構造モデ ルの解析を行い、サステナブルビル構造システムの成立について検 証を行う。本研究は、新接合方法の力学的特性のディテールを解明 することを目的とするのではなく、地球環境問題に対して、構造か らの新しいアプローチを提案することを目的としている。

\section{2. 梅造システムの提索}

\section{1 䠣造システムの枚要}

本構造システムは、図 2 に示すように接合部に曲げモーメントが 作用する時、接合部が離間するまでは第 1 段階として、剛接合とほ ぼ同様の歄性を有する。小規模の地震時はこの剛性によって、建物 の使用性を満足させる。さらに曲げモーメントが作用すると、接合 部の離間後から全ての銅棒が塑性化する直前までの第 2 段階に進み、 第 1 段階よりも㓮性が低下する。中・大規模の地震時は接合部の剛 性が小さくなることで、いわゆる半剛接合状態となり、主架構に損 䇚を与えず、ブレースによる効率のよいエネルギー吸収を行うこと ができる。そして、巨大地震時に大きな曲げモーメントが作用する と、鋼棒の塑性化が進み、第 3 段階となり、ほほピン接合と同様の 性能を示す。万が一、数箇所の柱梁接合部がこの段階に至っても、そ
の他の柱梁接合部が第 2 段階であればそれらの剛性は元に戻るため、 建物全体として残留変形はあまり生じることがない。

\section{2 橉造システムにおける接合方法}

新接合方法の概要図を図 3 に示す。新接合方法は、梁端部にブ ロック状の接合部ユニットを溶接する。接合部ユニットはブロック 状の形状をしたものであればよく、例えばH形鋼、鋼管、平鋼を溶 接したものが考えられる。必要に応じてリブプレート等を設ける。 接合部ユニットには、本体部分の両端部にプレートを設ける。この プレートには長い接合用の鎆棒(以下、鋼棒)が貫通する穴を設ける。 柱部材と接触する側のプレートには、円形断面としたナットがぎり ぎり入る穴をあけることで、ナットをシアキーとして鎆棒の塑性後 もせん断力を层達できるようにした。また、柱部材の接合部ユニッ トと接触するフランジにも鋼棒の貫通する穴を設け、その穴に鋼棒 を通し、初期張力を入れて締め付けるものである。銅棒の種類は首 下の長い高力ボルト、ワンサイドボルト、両端部をねじ切りした銅 棒等が挙げられる。スプリットティー等の従来の半剛接合は、T字 断面の接合要素や接合部に用いるボルト等の設計を個々に行う必要 がある。この接合方法は、接合部性能を決定する部材が銅棒のみで あるため、鎆棒の設計が接合部の設計となり、設計が極めて容易に なる。また、一般的なボルトは首下部分が短いために変形能力を期 待することはできないが、この接合方法に用いる鋼棒は、従来のボ ルトよりも長い鋼棒を使用するので、歪が小さく、変形能力に優れ ているため、巨大地震時にも破断等が生じることなく、接合部が安 
表 1 試験体一覧

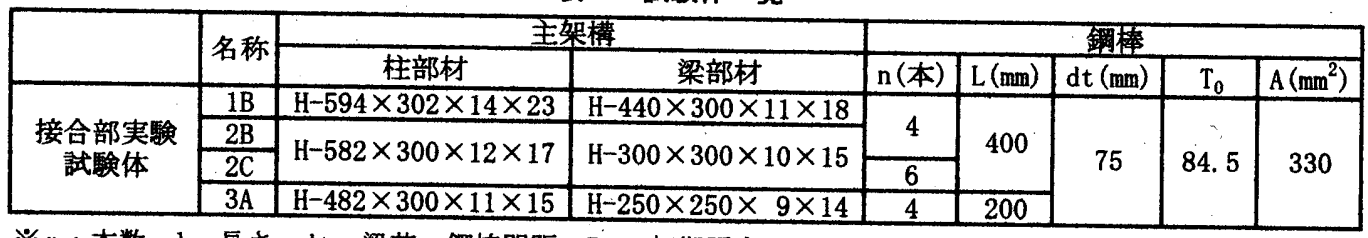

※ $\mathrm{n}$ : 本数 1 : 長さ $\mathrm{dt}$ : 梁芯一銅棒間距 $\mathrm{T}_{0}$ : 初期張力 $\mathrm{A}$ : 断面㮴

表 2 誈験体の機棫的性置

\begin{tabular}{|c|c|c|c|c|}
\hline & 妻材 & 隆伏耐力 $\left(\mathrm{N} / \mathrm{mm}^{2}\right)$ & 引張䩂力 $\left(\mathrm{N} / \mathrm{mm}^{2}\right)$ & 伸び $(\%)$ \\
\hline 銅棒 & $\mathrm{S} 45 \mathrm{C}$ & 475.3 & 768.3 & \\
\hline 主架樓 & SS400 & 304.0 & 451.5 & 30.8 \\
\hline
\end{tabular}

※鋼棒は引張試験結果 主架構はミルシートの值

定した回転性能を確保することができる。現場へは、工場で生産し た接合部ユニットを、梁端部と溶接した後に搬入することで、現埸 では柱と梁を鋼棒でつなぐだけになり、作業性も向上する。さらに 鎆棒接合のため、解体することが容易であり、部材のリユースが行 いやすい。リユースする際は接合部ユニットと銅棒を変更するだけ で、さまさまな接合部性能に対応できる。

尚、一般的に使用されるボルトよりも、長い接合部材を適用する 接合方法は、他 ${ }^{10}$ も研究されているが、柱梁接合部にエネルギ一吸 収を期待しているため、損傷制御構造という観点からは異なるもの である。

\section{3. 接合部实略}

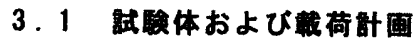

実䙴は図 4 に示すような柱梁接合部を取り出した実大T字型で行 う。柱と梁は 90 度回転させている。柱両端部をピン支持とし、梁端 に取り付けられたアクチュエータを用いて載荷する。図 5 に示すよ うに鋼棒は両端部を柱フランジ、梁リブプレートを挟むように取付 け、鋼棒 1 本に対して4つのナットを用いる。柱梁接合部に大きな 回転角が生じた場合、鋼棒は引張力によって塑性化し、残留変形が 生じる。これにより接合部が不安定になる。内側に取り付けられた ナットは引張力による塑性化後も圧縮力に抵抗できるようにしてい る。試験体として、柱と梁材のサイズの組み合わせ、銅棒の本数及 び長さを変化させた $1 \mathrm{~B} 、 2 \mathrm{~B} 、 2 \mathrm{C} 、 3 \mathrm{~A} の 4$ 体を使用する。図 2 に示 す第一段階の最大となる離關モーメントM $\mathrm{s}$ について、鋼棒が 4 本 の場合と 6 本の場合を式 $(1) 、(2)$ から求める。試験体一覧を表 1 に示す。鋼棒の配固は、1B、2B、3A は梁フランジ中心間距䧺の中心 位㯰より $75 \mathrm{~mm}$ 離れた位直とし、2C はその位直のほかに梁フランジ 中心間距離の中心位置にも配置する。接合部ユニットは梁部材と同 様のH鋼を用い、ボトルとの貫通するプレートは十分に厚いプレー トを溶接し、補強リブを中心に溶接する。また、柱フランジ部にも

銅棒が 4 本

$$
\begin{aligned}
& M_{s}=2 T_{o}\left(d_{c}-d_{t}\right)+2 T_{o}\left(d_{t}+d_{c}\right) \\
& =4 T_{o} d_{c} \\
& M_{s} \text { :雄間モーメント } T_{0} \text { : 初期镸力 } \\
& d_{c} \text { : 染芯一梁フランジ間距雄 } \\
& \text { 羭椣が } 6 \text { 本 }
\end{aligned}
$$

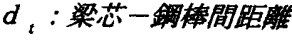

$$
\begin{aligned}
& M_{s}=2 T_{o}\left(d_{c}-d_{t}\right)+2 T_{o}\left(d_{t}+d_{c}\right)+2 T_{o} \cdot d_{c} \\
& =6 T_{o} d_{c}
\end{aligned}
$$

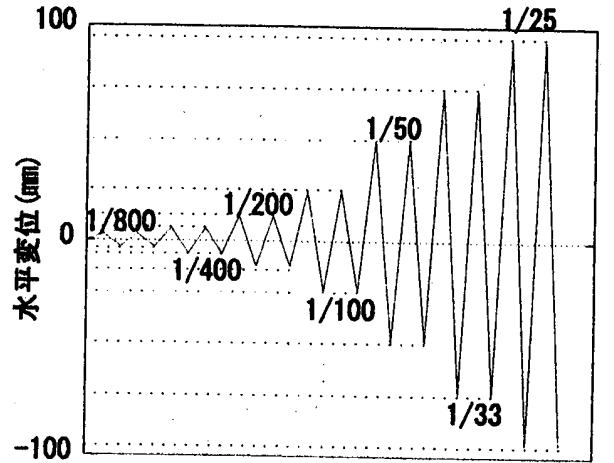

图 6 蔽臀歴

十分に厚い補強プレートを設けた。試験体の機械的性質を表 2 に示 す。鈵棒の降伏酎力については、引張試験における比例限界である、 歪が $0.25 \%$ に達した時点における応力度とする。

鋼棒を締め付ける時の初期張力は、鎆棒の降伏耐力の $1 / 3$ とする。 初期張力は、鋼棒中央部に取り付けた歪ゲージにより確認する。

載荷はアクチュエータの水平変位を層間変形角と対応させ、水平 変位を漸增させ正負交番䋖返し載荷で行う。載荷履歴は、図 6 に示 すように層間変形角に対応した办平変位を各振幅 2 回ずつとする。

\section{2 英联結果}

図 7 に各試験体の梁部材の回転支点の曲げモーメントと柱梁接合 部の回転角の関係を示す。層間変形角 $1 / 200$ 相当の水平変位までは すべての試験体において弾性域であった。鋼棒の塑性化は回転角 $0.005 \sim 0.01 \mathrm{rad}$ の間で生じた。その㻮、鋼棒の塑性化直後に初期 張力による材間圧縮力が 0になるのではなく、塑性化の進展により、 初期張力が解放されると材間圧縮力が 0 となる。そのため材間圧縮 カが 0 になるまでは回転角 0 から 1 次勾配で荷重が増加し、初期張 力が解放された分に比例して、半剛の状態に移行する晟間荷重が低 下する。最大回転角 $0.01 \mathrm{rad}$ に達して以降は、スリップモデルに近 い傾向を示した。これは塑性化した鎆棒の圧縮耐力が梁自重による 圧縮力よりも大きいために変形が残ってしまい、梁が浮いた状態に なったためである。2C 以外の試験体は、柱フランジ及び接合部ユ ニット面外変形は生じなかった。

\section{3 考察}

鋼棒の引張試験の結果を図 8 に示す。これに基つき、降伏耐力後、 腩性が低下し実験結果の最大耐力点と交わる、降伏後の歪を考庶し たモデル 1 と、降伏耐力後も最大耐力まで用性の低下がなく、最大 

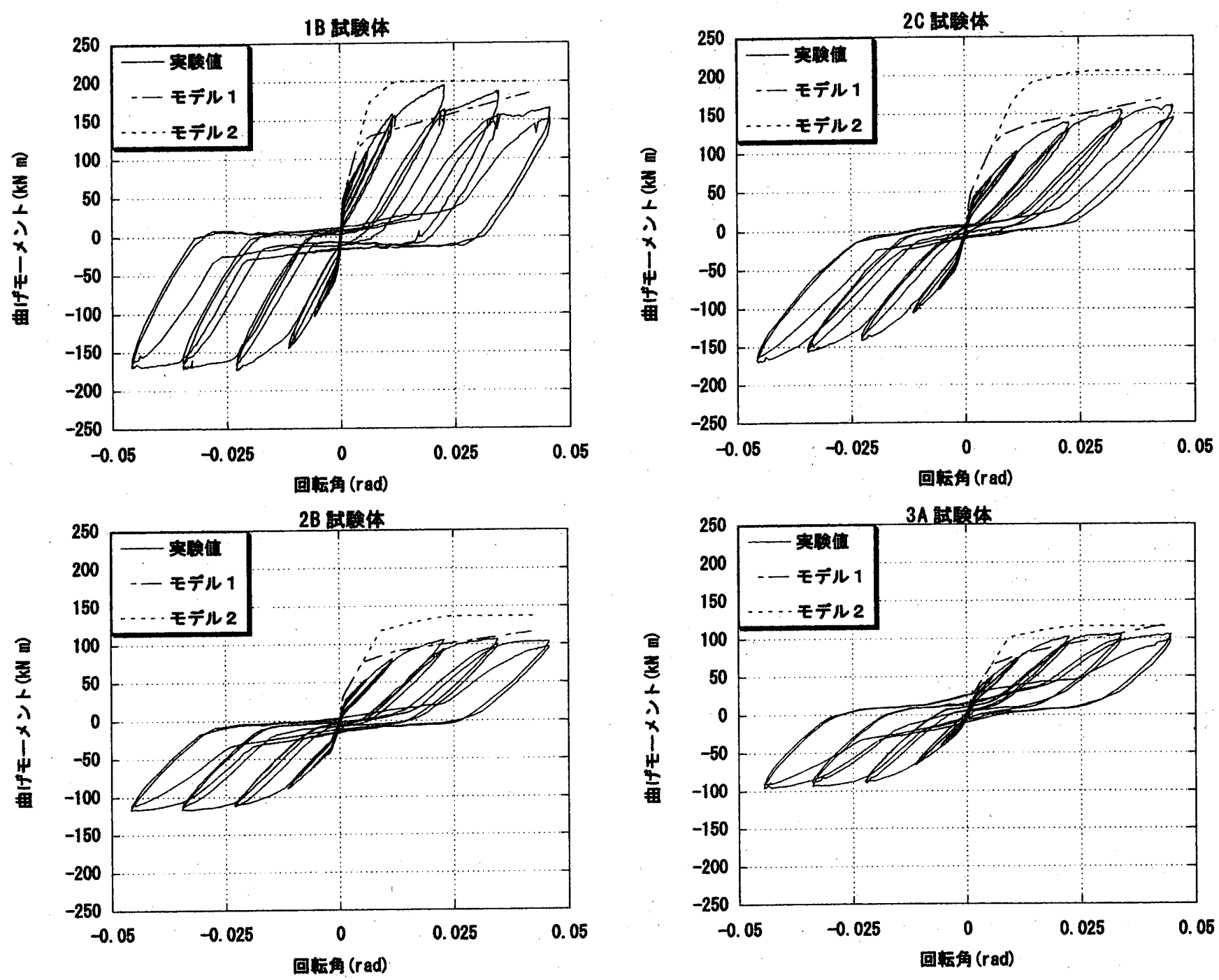

图 7 接合部M- $\theta$ 图

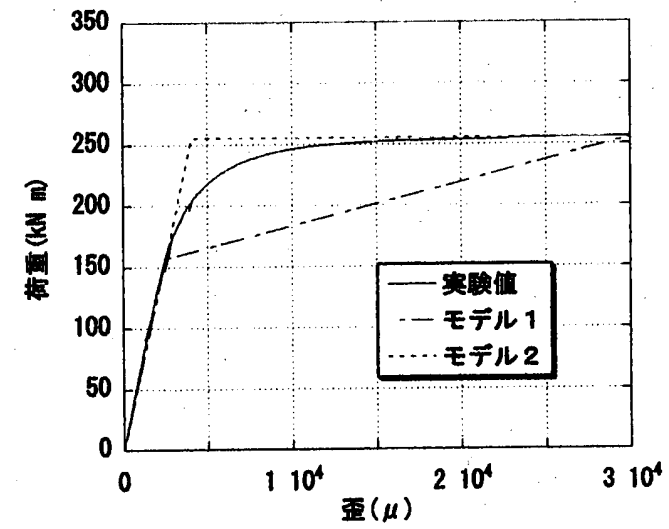

图8接合鐳棒のモデル化

耐力後は剛性が 0 となる、降伏後の荷重を考虑したモデル 2 を設定

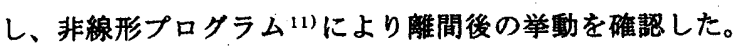

図 7 に示すように全ての試検体において、離間後の剛性は実験值 が解析值より低い結果となっている。また、モデル 2 による解析結 果の最大耐力は、実験值を上回る值となっている。離間後の剛性が 低くなった原因は、鋼棒に軸力だけでなく曲げが作用し曲げ変形が
生した事による。耐力の低下についても鋼棒に作用した曲げモーメ

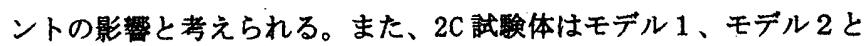
もに 2 次勾配以降の曲げモーメントが解析值より実駼值が低い值を 示している。これは鋼棒と接合されている柱フランジが湾曲し、塑 性化した影䇾により最大值が解析値よりも低い值となったためであ る。

\section{4 接合部のモデル化}

$1 \mathrm{~B}$ 試匼体の荷重一変形関保から柱及び梁の弾性変形（計算值）を 差し引き、接合部の荷重一変形関係を抽出する。抽出した荷重一変 形関係から䧺間モーメント $\mathrm{M}_{\mathrm{s}}$ 、半剛限界モーメント $\mathrm{M}_{\mathrm{SEM}} 、 \theta_{\mathrm{s}}$ 及 び $\theta_{\mathrm{SEM}}$ を求め、各勾配時の剛性を求める。その結果を用いて図 9 に示すようなトリリニアスリップ型モデルとする。 $\theta_{\mathrm{s}}$ に達するま では、図に示される番号で 1 の直線上で荷重が上䙹し、同様に低下 する。初めて倚重が $\theta_{\mathrm{s}}$ を超えるとき、 $\theta_{\mathrm{SEM}}$ に達するまでは、1， 2 の順で荷重が上昇し、3，4 の剛性で荷重が低下する。2回目以 降は、4，5の順に荷重が上昇する。更に変形が進行し、 $\theta_{\mathrm{SEM}}$ を 初めて超えるとき、6 の㴊性となり、変形が進む。荷重が低下する 際は、7，8の剛性で低下する。2回目以降は、9、10、11の順に 


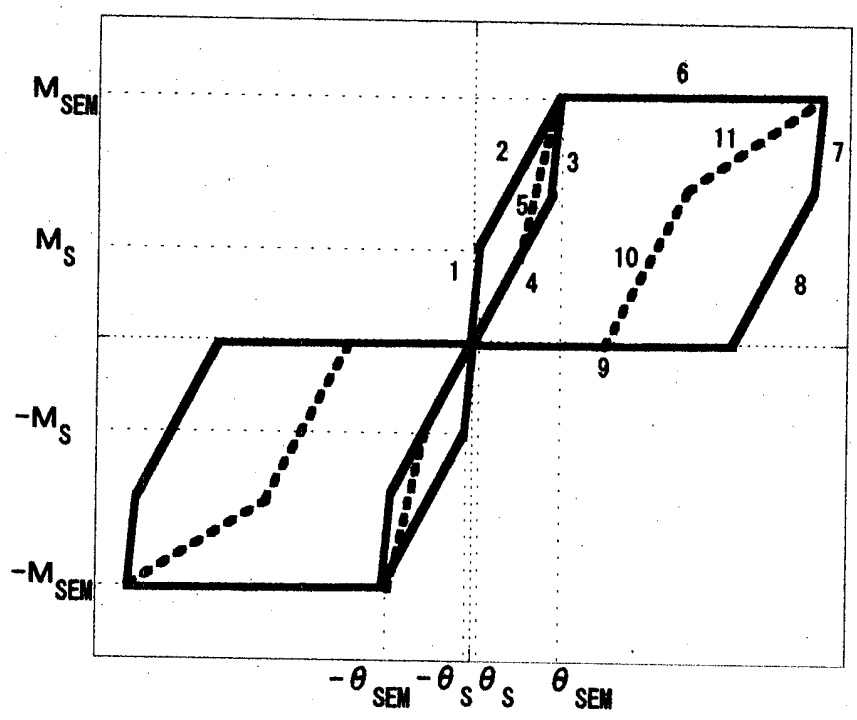

图 9 接合部の㕍歴モデル

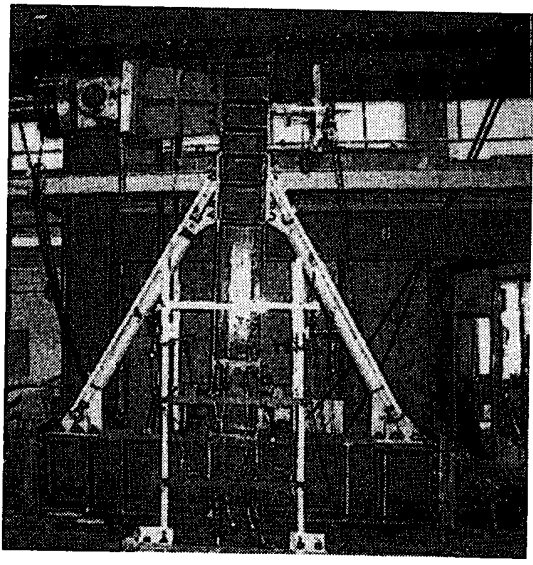

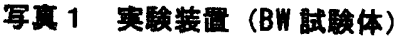

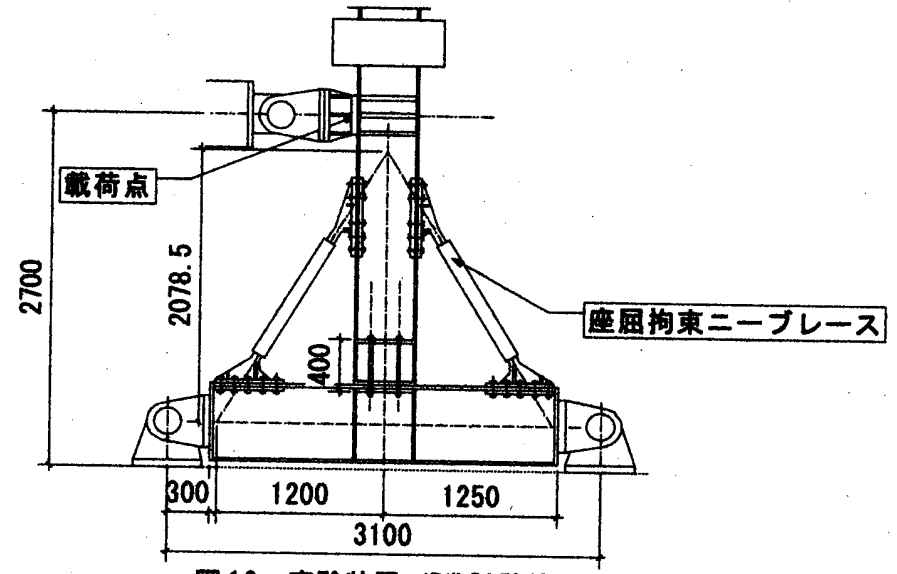

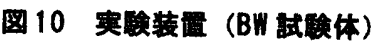

表 3 試駸体一管

\begin{tabular}{|c|c|c|c|c|c|c|c|c|c|}
\hline & 名称 & & 翠構 & & & 金岡棒 & & & フレース \\
\hline & 石怕 & 柱部材 & 梁部材 & $\mathrm{n}$ (本) & $L(\mathrm{~mm})$ & $\mathrm{dt}(\mathrm{mm})$ & $T_{0}$ & $A\left(\mathrm{~mm}^{2}\right)$ & 本数 \\
\hline $\begin{array}{c}\text { 部分架構実鉿 } \\
\text { 試雊体 }\end{array}$ & $\frac{\mathrm{BW}}{\mathrm{BS}}$ & $\mathrm{H}-488 \times 300 \times 11 \times 18$ & $\mathrm{H}-294 \times 302 \times 12 \times 12$ & 4 & 400 & 75 & 84.5 & 330 & $\frac{2 \text { 本 }}{1 \text { 本 }}$ \\
\hline$\frac{7 V-\pi}{6 n: \text { 本数 }}$ & 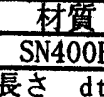 & $\frac{\frac{1}{\text { 断面形状 }}}{\text { PL-22X80 }}$ & 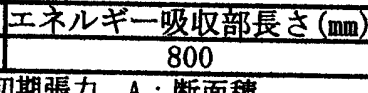 & & 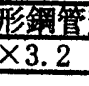 & $L=1100$ & & & \\
\hline
\end{tabular}

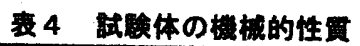

\begin{tabular}{|c|c|c|c|c|}
\hline & 秦材 & 隆伏耐力 $\left(\mathrm{N} / \mathrm{mm}^{2}\right)$ & 引張耐力 $\left(\mathrm{N} / \mathrm{mm}^{2}\right)$ & 伸び(\%) \\
\hline 鋼棒 & $\mathrm{S45C}$ & 475.3 & 768.3 & \\
\hline 主架䧿 & $S S 400$ & 304.0 & 451.5 & 30.8 \\
\hline ブレース & SN400B & 263.4 & 448.1 & 35.5 \\
\hline
\end{tabular}

※鋼棒は引張試験結果 主架構はミルシートの值

$$
\text { ブレースは素材引張試験 ( } 5 \text { 号) の結果 }
$$

荷重が上昇する。2 次勾配の剛性低隇率は実験值より0.041 とし、 3 次勾配の剖性低減率は、実験における層間変形角 $1 / 50$ 以降の 2 回目の履歴結果では制性がほほ0のため、0.001 とする。また、軸 方向に関しては接合部にモーメントが生じると鋼棒に引張力が生じ、 引張耐力が堿少する。そのため引張側の降伏耐力を $1 / 10$ とする。せ ん断については、鋼棒の、柱フランジ側のナットに挟まれた部分が せん断力を負担するため、鋼棒の機械的性質により、モデル化する。 このモデルは、 5 章における骨組の解析に用いる。

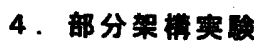

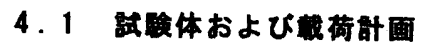

新接合方法とブレースを方杖状に設膡した場合の基本的挙動を確 認するために部分架構実駼を行った。本実験の目的は、ブレースが 安定したエネルギー吸収が行えるか、接合部ブレースを設置した場 合でも、鋼棒の破断等がなく変位に追従できるかを確認することで ある。ブレースが組み込まれる以外は接合部実䍄と同様である。試 䀦体として、ブレースが 2 本のものをBW、1 本のものをBS とする。 写真 1 と图 10 はBW 試験体を示す。BW 試嗝体は既報の構造システム 4) と同梯にブレースを設膡し、柱梁接合部を提案する接合方法とす るものであり、BS 試験体は梁上部のブレースを取り除き、使用鋼材 量の軽減と施工性、意匠性の向上を図る構造システムを想定するも のである。本実駼では、円形鋼管により芯材を座届拘束し、カセッ 

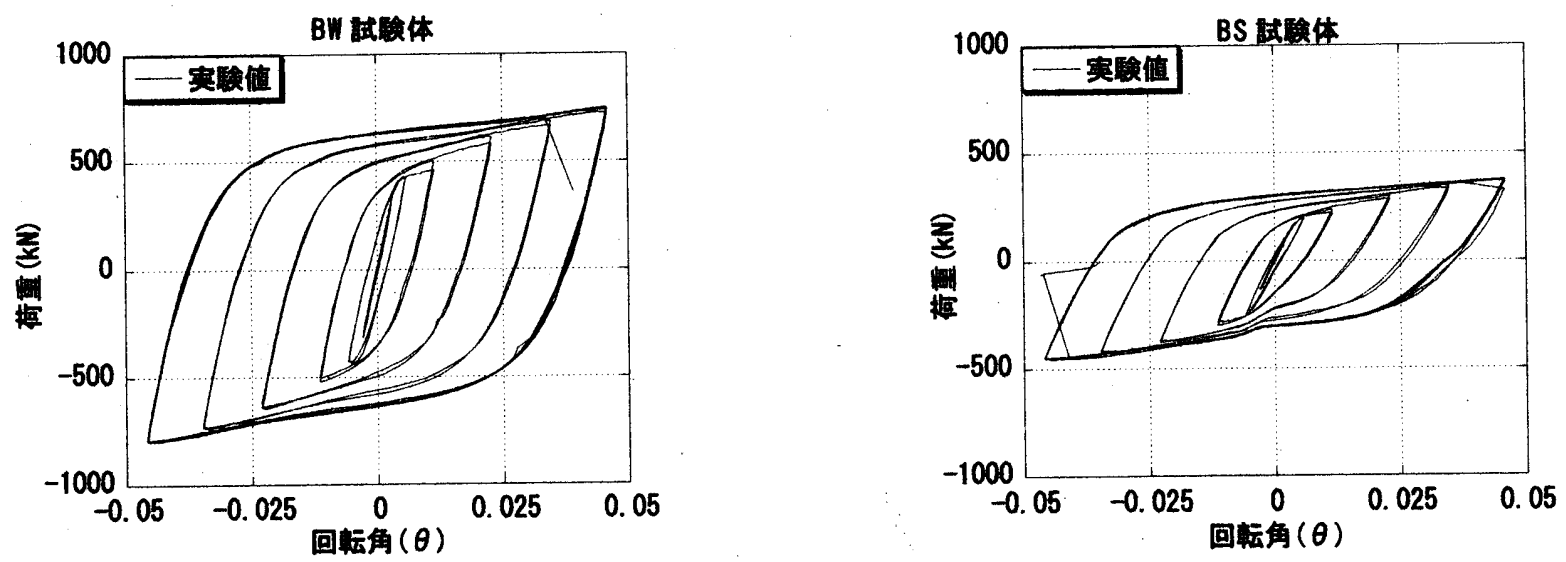

图 11 荷点 $P-\theta$ 圆
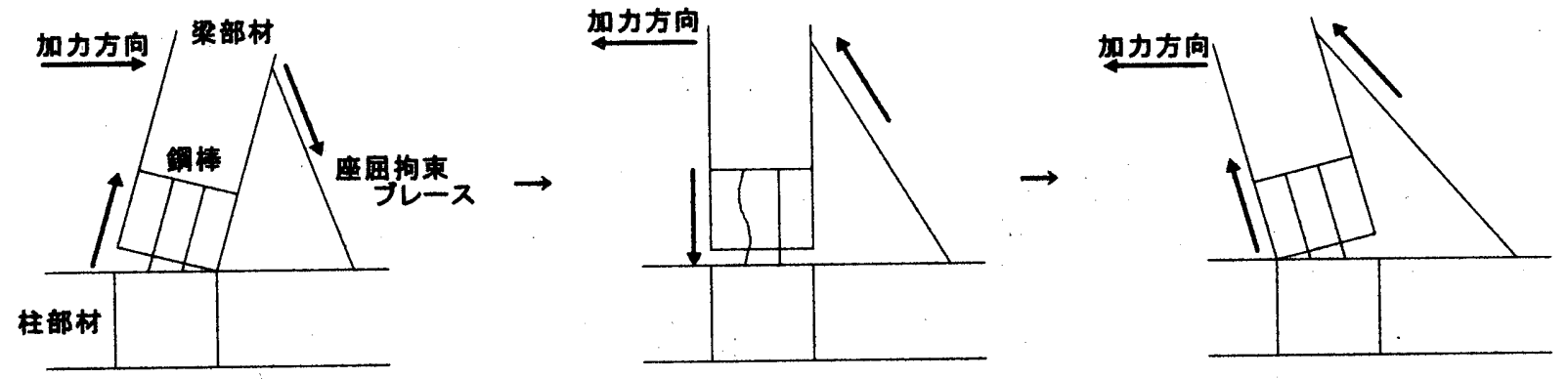

图12接の変化

トを一体としたブレースを用いる。試験体一覧を表 3、試㙠体の機 珹的性質を表 4 に示す。

\section{2 实唤結果}

ブレース付試験体では、接合部実験同倳、図6に示す载荷履歴で 載荷した後、変形角 $1 / 25$ に相当する振幅で耐力低下がみられるま で載荷を行った。各試験体の載荷点の水平荷重 $\mathrm{P}$ と回転角 $\theta$ の関係 を図 11 に示す。BW 試験体では変形角 $1 / 25$ 相当 9 回目で片側のブ レースが破断し、実験を終了した。BS試駼体では $1 / 25$ 相当 7 回目 にブレースが破断し実験を終了した。ブレースなしの試験体と同様 に梁が浮いてしまう現象はみられたが、BW試験体では安定した性状 を示した。BS 試験体ではブレース引張側で水平変位0付近で荷重の 低下があるが、これはブレースと離れた方の鋼棒 2 本が大きく変形 していたことから、図 12 に示すとおり、この鋼棒に座屈が生じ、刪 性が低下したと考える。そのため水平変位のからマイナスに移行す ると鎆棒が引張側となるために、耐力が安定する。しかし、ブレー ス压縮時の吸収エネルギーの総和と引張時の総和はほほ同等なこと から安定したエネルギー吸収が行われているといえる。

\section{5. 標造モテルの模证}

\section{1 解析モデル}

接合部実験における接合部性能、部分架構実験におけるブレース の安定した挙動の確認を踏まえ、構造モデルの検証を行う。地上 7 階建ての中規模鉄骨造集合住宅 ${ }^{1)}$ を想定する。階高 $2.75 \mathrm{~m} の 7$ 層、 $6 \mathrm{~m} \times 6$ スパンである。既往の研究1)で用いられた純ラーメン粠造 の建物を基本モデルとする。梁上下部にブレースを組み込んだ建物 を 4 ブレース樓造モデル(以下、4 4 モデル)とする。4 モデルを図 13
に示す。また、 4 モデルの梁上部のブレースを取り除いた建物を 2 ブレース構造モデル(以下、2 モデル) とする。2 モデルを図 14 に 示す。上記の 3 つの解析モデルの解析を行い、性能比較と構造シス テム成立の検証を行う。各モデルの主要部材一覧を表 5 に示す。

ブレースを設膡するモデルでは、ブレースの梁に対する角度は 30 度、長さは柱と梁の芯々から $2.4 \mathrm{~m}$ である。また、ブレースはガセッ ト部分とエネルギー吸収部分を区別し、3分割する。柱材は梁接合 部とブレース接合部とで 3 分割し、梁材も同様に 3 分割する。柱梁 接合部はモデル化した接合部を 3 章の 4 で記述している性能を有す る回転バネ、水平バネ、せん断バネで置換する。設計条件は、1 次 設計で層間変形角 $1 / 200$ 以内、ブレースは弾性域であることとす る。2 次設計では、1 次設計の 2 倍の水平力に対しても主架構は曲 げ、軸力、せん断ともに弾性域であることとする。

予備解析を行った結果、龬棒の美材が $\mathrm{S} 45 \mathrm{C}$ では常時荷重時に接 合部が離間してしまったため、機械的性質からステンレス鎆の SUS630を採用することとし、ヤング率、剛性について接合部モデル を補正して解析する。

\section{2 解析条件}

解析の条件は、既往の研究帛を参考に、以下のように定める。 (1)鋼材のヤング率 $\mathrm{E}$ は $205 \mathrm{kN} / \mathrm{mm}^{2}$ とし、ヤング率に対する塑性勾配

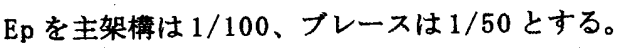

(2)減衰は、剛性比例型隇衰とし、1 次固有周期に対する堿衰定数を $2 \%$ とする。

(3)採用する地震動は観測地震動としてE1 centro NS、神戸海洋気 象台 NS、Taft EW、八戸 EW、および日本建築センター作成による 模擬地震動（センター波）を用いる。 


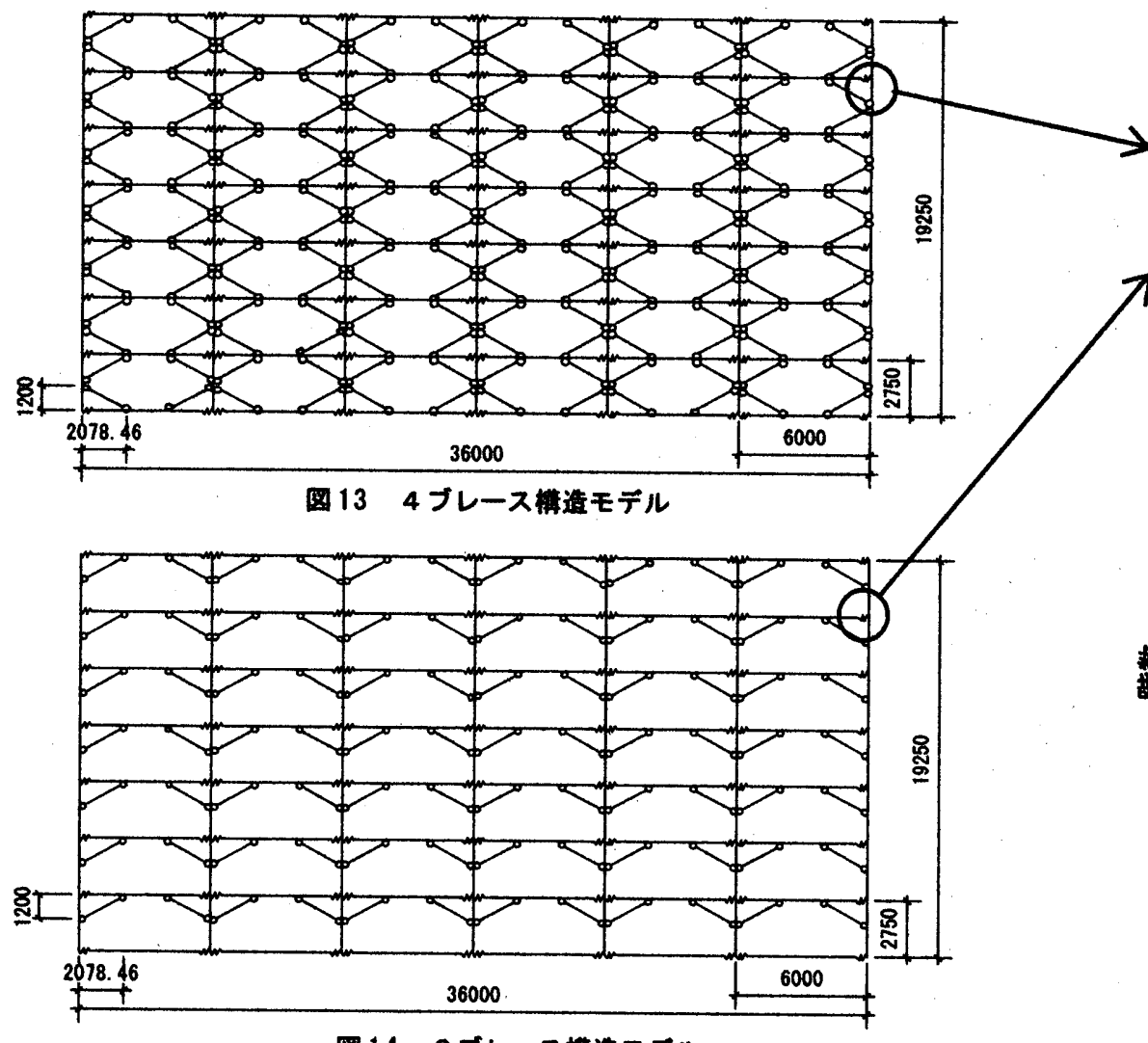

图14 2ブレース筑造モデル

表 5 - 主要部材一算

\begin{tabular}{|c|c|c|c|c|c|c|}
\hline \multicolumn{7}{|c|}{ 基本モテル } \\
\hline \multirow{2}{*}{ 階 } & \multicolumn{2}{|l|}{ 梁部材 } & \multicolumn{2}{|l|}{ 玨部材 } & \multicolumn{2}{|c|}{ FVース } \\
\hline & 部材断面 & 素材 & 部材断面 & 妻材 & $\left(\mathrm{mm}^{2}\right)$ & 秦材 \\
\hline 8 & $\mathrm{H}-440 \times 300 \times 11 \times 18$ & $S S 400$ & & & & \\
\hline 7 & $\mathrm{H}-440 \times 300 \times 11 \times 18$ & SS400 & $\mathrm{H}-594 \times 302 \times 14 \times 23$ & SS400 & & \\
\hline 6 & $\mathrm{H}-440 \times 300 \times 11 \times 18$ & $\mathrm{SS} 400$ & $\mathrm{H}-594 \times 302 \times 14 \times 23$ & $S S 400$ & & \\
\hline 5 & $\mathrm{H}-440 \times 300 \times 11 \times 18$ & SS400 & $\mathrm{H}-594 \times 302 \times 14 \times 23$ & SS400 & & \\
\hline 4 & $\mathrm{H}-440 \times 300 \times 12 \times 22$ & SS400 & $\mathrm{H}-594 \times 302 \times 14 \times 23$ & SS400 & & \\
\hline 3 & $\mathrm{H}-440 \times 300 \times 12 \times 22$ & SS400 & $\mathrm{H}-594 \times 302 \times 16 \times 25$ & SM490 & & \\
\hline 2 & $H-440 \times 300 \times 12 \times 22$ & SM490 & $\mathrm{H}-594 \times 302 \times 16 \times 25$ & SM490 & & \\
\hline 1 & $\mathrm{H}-440 \times 300 \times 12 \times 22$ & SM490 & $H-594 \times 302 \times 16 \times 25$ & SM490 & & \\
\hline & & & 箸造モデル & & & \\
\hline 8 & $\mathrm{H}-250 \times 125 \times 6 \times 9$ & SN400 & & & 1050 & SN400 \\
\hline 7 & $\mathrm{H}-346 \times 174 \times 6 \times 9$ & SN400 & $\mathrm{H}-150 \times 150 \times \quad 7 \times 10$ & SN400 & 1000 & SN400 \\
\hline 6 & $\mathrm{H}-396 \times 199 \times 7 \times 11$ & $\mathrm{SN} 400$ & $\mathrm{H}-175 \times 175 \times 7.5 \times 11$ & SN400 & 1000 & SN400 \\
\hline 5 & $\mathrm{H}-400 \times 200 \times \quad 8 \times 13$ & SN 400 & $\mathrm{H}-250 \times 250 \times \quad 9 \times 14$ & SN400 & 950 & SN 400 \\
\hline 4 & $\mathrm{H}-450 \times 200 \times \quad 9 \times 17$ & SN400 & $\mathrm{H}-250 \times 250 \times 9 \times 14$ & SN400 & 900 & SN 400 \\
\hline 3 & $\mathrm{H}-450 \times 200 \times \quad 9 \times 17$ & $\mathrm{SN} 400$ & $\mathrm{H}-300 \times 300 \times 10 \times 15$ & SN400 & 800 & SN 400 \\
\hline 2 & $\mathrm{H}-450 \times 200 \times \quad 9 \times 17$ & SN400 & $\mathrm{H}-300 \times 300 \times 10 \times 15$ & SN400 & 700 & SN400 \\
\hline 1 & $\mathrm{H}-400 \times 200 \times 8 \times 13$ & SN400 & $H-300 \times 300 \times 10 \times 15$ & SN400 & 700 & SN400 \\
\hline & & & Eテル & & & \\
\hline 8 & $\mathrm{H}-250 \times 125 \times$ & SN400 & & & 1700 & SN400 \\
\hline 7 & $\mathrm{H}-350 \times 175 \times 6.5 \times 9$ & SN400 & $\mathrm{H}-250 \times 250 \times \quad 9 \times 14$ & SN400 & 1650 & 400 \\
\hline 6 & $\mathrm{H}-446 \times 199 \times \quad 8 \times 12$ & SN 400 & $\mathrm{H}-300 \times 300 \times 10 \times 15$ & SN400 & 1550 & SN400 \\
\hline$\underline{5}$ & $\mathrm{H}-446 \times 199 \times \quad 8 \times 12$ & SN400 & $\mathrm{H}-390 \times 300 \times 10 \times 16$ & SN400 & 1400 & SN400 \\
\hline 4 & $\mathrm{H}-450 \times 200 \times$ & SN400 & $\mathrm{H}-390 \times 300 \times 10 \times 16$ & SN400 & 1200 & SN400 \\
\hline 3 & $\mathrm{H}-496 \times 199 \times$ & SN400 & $\mathrm{H}-390 \times 300 \times 10 \times 16$ & SN400 & 1050 & SN400 \\
\hline$?$ & $\mathrm{H}-596 \times 199 \times 10 \times 15$ & SN400 & $\mathrm{H}-440 \times 300 \times 11 \times 18$ & SN400 & 750 & SN400 \\
\hline & $\mathrm{H}-596 \times 199 \times 10 \times 15$ & SN400 & $\mathrm{H}-440 \times 300 \times 11 \times 18$ & SN400 & & \\
\hline
\end{tabular}

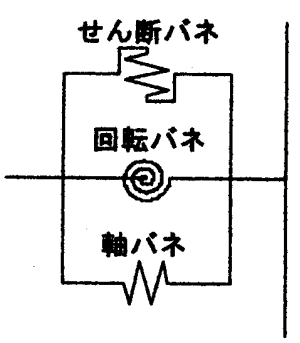

接合部拡大图
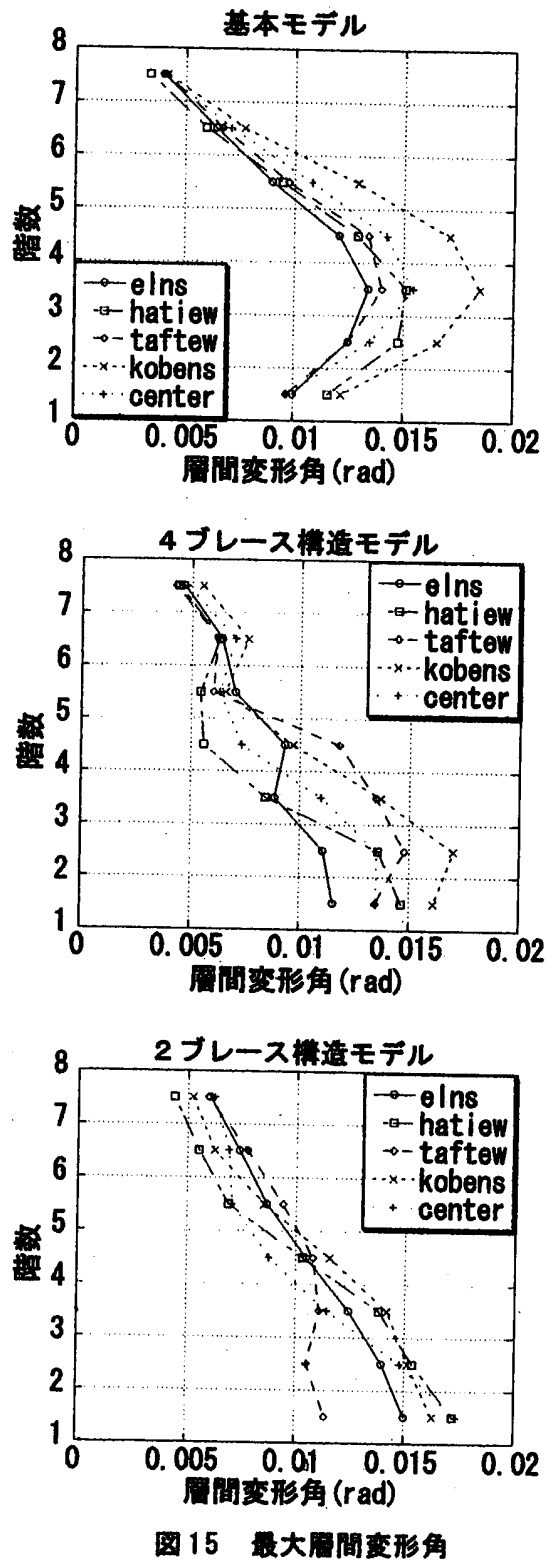

(4)観測地震動について、地動最大速度で 2 つレベル $(0.25 、 0.5 \mathrm{~m} /$ s）に基浅化し、模㩆地震動についてはレベル 1 の加速度の地震波 を 1 倍、2 倍したものを用いる。

(5)地震継繶時間は、残留変形を確認するために日本建築センターで 配布している地震波の継続時間に 5 秒以上の自由振動をさせる時間
を付加したものとする。

(6)非線形解析法は逐次積分法、時刻歴応答解析手法は、Newmark $\beta$ 法（ $\beta=1 / 4 ）$ を用い、弾塑性解析プログラム (SNAP Ver. 2) を使 用する。 


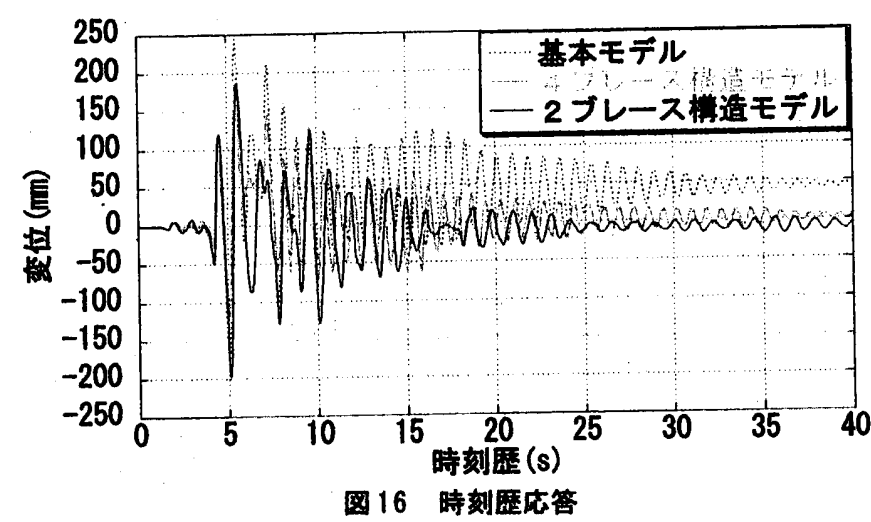

\section{3 析辐果}

レベル 2 時の最大層間変形角を図 15 に示す。いずれのモデルも純 ラーメン構造である基本モデルとほほ同等の性能を有している。最 大層間変形角は、基本モデルは神戸 NS 波で $1 / 54 、 4$ モデルでは神 戸 NS 波で 1/59、2 モデルではセンター波で1/58 である。接合部 の最大回転角は 2 モデルの八戸 $\mathrm{EW}$ 波レベル 2 時で $0.017 \mathrm{rad}$ であ り、2 章で述べた第 2 段階であり、半剛域内である。

最大残留変形は、基本モデルでは神戸 NS 波で $1 / 436 、 4$ モデル ではセンター波で1/1227、2 モデルではE1 centro NS 波で $1 / 1203$ である。全モデルで比較的大きな応答を示したレベル 2 時の神戸 NS 波の時刻歴応答を図 16 に示す。この図からも分かるように基本モデ ルでは残留変形が大きく残っているが、ブレースの設置された 4 モ デルと 2 モデルではほとんど残留変形が見られない。

表 6 に主架構の最大塑性率、表 7 に 4 モデルと 2 モデル、および BW 試験体と BS 試験体のブレースの最大塑性率および等価累積塑性 変形倍率を示す。基本モデルでは主架構が塑性化しているのに対し、 4 モデルおよび 2 モデルともにレベル 2 時でも主架構は弾性域であ り、大地震後も主架構をリユースすることが可能である。また、ブ レースを実験值と比較した場合、十分な余裕度があり、破断等が生 じることなく安定したエネルギー吸収をすることが可能である。

\section{6. 蛕既}

環境負荷削減を目指したサステナブルビル構造システムを着想し、 それの力学性能を把暒するために、接合部実験と部分架構実験を行 い、想定する構造システムの基本的挙動を確認した。更に、接合部 の力学モデルを用いた全体粠造モデルを用いて解析を行い、その考 察をした。以下の結論を得た。

（1）建築樓造の長寿命化と部材のリユースを考虑したサステナブ ルビル構造システムの基本的性質を確認した。

（2）実験により、座屈拘束ニーブレースは安定したエネルギー吸 収を行うことができることを確認した。

（3）本構造システムは損稘制御構造であり、従来型の純ラーメン 跷造と同等以上の棬造性能を有する。
表 6 主架攘の最大望性率

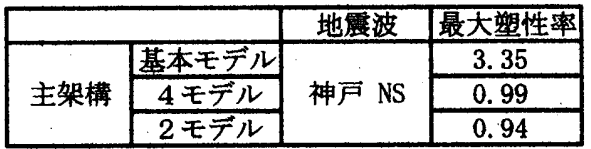

表 7 ブレースの最大盟性率および等洒累㮴变形倍本

\begin{tabular}{|c|c|c|c|c|}
\hline & & 地震波 & 最大塑性率 & 等価累積塑性変形倍率 \\
\hline \multirow{4}{*}{ ブレース } & 4 モデル & 神户 NS & 16.8 & 64 \\
\hline & 2 ¿テル & センター波 & 13.7 & 254 \\
\hline & BW試䮙体 & $=$ & 23.2 & 862 \\
\hline & BS試験体 & & 32.6 & 759 \\
\hline
\end{tabular}

（4）本構造システムの柱梁接合方法は、第 1 段階から第 3 段階の 㓮性変化がある力学特性を有する。

本論文は、地球環境問題に対して、構造的にアプローチすること を目的とし、そのための構造システムをトータル的に提案するもの ある。今後、本椿造システムのディテールについて探求していく予 定である。

\section{的辞}

本研究は、平成 14 年度（社）日本鉄龬連盟 建築銅構造研究助成 金・励金、および平成 13、14 年度文部科学省科学研究費補助金 （基盤研究（B）：課題番号 13450229）の助成を受けた。付記して謝 意を表する。

[参考文献]

1)岩田 衛、堂野前等、久松雄治:建策鉄骨構造のライフサイクルにおける䅫境 負荷削减のシナリオとその評価、日本建策学会構造系䠼文集、第533号、pp. 167173、2000. 7

2)山田哲、黒川礼子、會澤貴浩、岩田 衛: 廃望物量と $\mathrm{LCCO}_{2}$ 着目した 骨造建物における境負荷の評価、日本建築学会構造系詇文集、第554号、pp. 131137、2002. 4

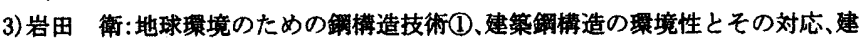
築雑誌（技術ノート）、vol. 118、No. 1499、pp. 58-59、2003:1

4)會澤贵浩、黒川礼子、山田 哲、岩田 衞:サステナブル中首ビル構造システ

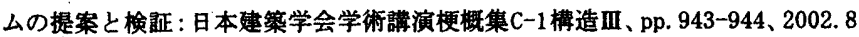
5)和田 童、岩田 衛、清水敬三、安部重孝、川合廣樹: 建策物の損伤制御設尌、 丸善株式会社、1998.9

6)竹内一郎、岡田忠義、井上一朗、吹田敬一郎、張シシュン: 宇野啺芳：高力ボ ルト接合を用いたH形鋼柱梁制振システムの力学的举動、日本建策学会学術講演㮀 概集 C-1 構造而、pp. 841-844、2001.9

7)岩崎晃久、竹内一郎、井上一朗、吹田啓一郎、高裕治、宇野棏芳: エネルキー

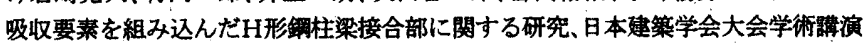
概要集、pp. 639-640、2002.8

8) 前田泰史、吉敷祥一、岡田 健、鈴木一茾、竹内徽、竹内一郎、山田哲、和 田 章:塑性化スプリットティーを用いたドライフレームに関する研究、日本建策 学会大会学術講演梗概集、pp. 653-660、2002.8

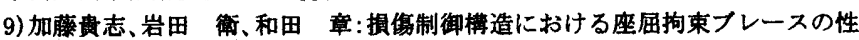
能語価、日本建築学会践造系論文集、第 552 号、pp. 101-108、2002.2

10)山田大彦、田辺恵三:弾性間接接合を用いた銅粠造骨組とその動的特性、日本 建勧学会大会学㣪講演梗概集 C-1 構造吕、pp. 825-826、2001.9

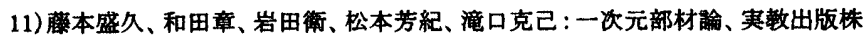
式会社、1981 